\title{
Assessment of Pig Disease Prevention of Smallholder Farmers and Village Animal Health Workers in Rural and Peri-Urban Cambodia
}

\author{
Bunna Chea1, Kroesna Kang1, Jessie Vipham², Lisa Tokach ${ }^{3}$, Mike Tokach ${ }^{2}$ \\ ${ }^{1}$ Faculty of Veterinary Medicine, Royal University of Agriculture, Phnom Penh, Cambodia \\ ${ }^{2}$ Department of Animal Sciences and Industry, Kansas State University, Manhattan, USA \\ ${ }^{3}$ Abilene Animal Hospital PA, Abilene, Kansas State, USA \\ Email: bunna_chea@rua.edu.kh
}

How to cite this paper: Chea, B., Kang, K., Vipham, J., Tokach, L. and Tokach, M. (2020) Assessment of Pig Disease Prevention of Smallholder Farmers and Village Animal Health Workers in Rural and Peri-Urban Cambodia. Open Journal of Animal Sciences, 10, 572-591.

https://doi.org/10.4236/ojas.2020.103037

Received: June 5, 2020

Accepted: July 20, 2020

Published: July 23, 2020

Copyright $\odot 2020$ by author(s) and Scientific Research Publishing Inc. This work is licensed under the Creative Commons Attribution International License (CC BY 4.0).

http://creativecommons.org/licenses/by/4.0/

\section{(c) (i) Open Access}

\begin{abstract}
Biosecurity measures are essential for protecting pig health, however, these practices are not always utilized by smallholder farmers in Cambodia. This study aimed to assess the knowledge and practices, in terms of pig biosecurity measures, of individual stakeholders involved in pig production in rural and peri-urban households in Cambodia. A survey tool was developed and administered using Kobotoolbox, an online electronic survey tool. Surveys were conducted in the provinces of Kampong Thom, Siem Reap, and Battambang during December 2017 to September 2018. There were 225 pig farmers, 43 village animal health workers (VAHWs), 3-district veterinarians (DVs), and 81 feed store owners enrolled in the study. Results showed that several biosecurity guidelines are not followed or well understood by farmers. Specific concerning practices included using natural boars, sharing pig equipment (e.g. scales), feeding kitchen waste, managing other livestock, handling manure, and not restricting access by visitors (VAHWs or DVs, boar owners, pig buyers, neighbors, and meat sellers). Thus, education of pig smallholder farmers and VAHWs on pig biosecurity is needed for improving pig health and production, economic value, and livelihood of smallholder farmers in Cambodia.
\end{abstract}

\section{Keywords}

Biosecurity, Knowledge, Practices, Pig Smallholder Farmers, Village Animal Health Workers

\section{Introduction}

Livestock production in Cambodia can be broken into two major groups: large 
animals (cattle and buffalo) and small animals (poultry and pigs). In recent years, the Cambodian Ministry of Agriculture, Forestry and Fisheries (MAFF) has estimated increases in the numbers of ducks, chickens, and pigs being produced in the country [1]. Furthermore, poultry and pig production are major sources of household income, with pork having the largest share of the livestock market in Cambodia.

Cambodia has three major types of pig production: smallholder, semicommercial, and commercial [2]. Of these production types, the largest percentage, roughly 90, is smallholder. Smallholders are mainly located in rural areas [3] and are relatively small (i.e. keeping 5 pigs or less; [2] [4]). Although small-scale pig production may not contribute to overall efficiency of pork production for Cambodia, many smallholder households rely on pigs for income. High mortality, low reproductive performance, and widespread malnourishment are major constraints for smallholder pig farmers [5] [6]; which can jeopardize livelihoods for smallholder households. Samkol et al. (2006) reported that the economic failure of Cambodian pig smallholders production is often due to high mortality of young piglets as farmers commonly buy piglets from middlemen at the time of the rice harvest and those piglets are generally not adapted to the smallholder environment and often cannot survive on poor quality diets [3].

Disease and mortality are major challenges in raising pigs. Disease outbreaks were considered one of the main constraints of pig production, along with expensive feed and low payment prices for the slaughter pigs [7]. Currently, several important pig diseases are circulating in Cambodia including Classical Swine Fever virus, Foot and Mouth Disease virus, Porcine Circovirus, highly pathogenic PRRSv, Aujeszky's virus, Mycoplasmas [7], and porcine cysticercosis [8]. Of these, it has been suggested that African Swine Fever and parasites place the largest health constraints on smallholder pig farmers [5]. However, Dione et al. (2018) reported that some pathogens including Streptococcus suis, Porcine circovirus type 2, Actinobacillus pleuro-pneumoniae, and Mycoplasma hyopneumonia have a high prevalence in smallholder pig production systems and might be silent killers, thus affecting productivity [9]. Furthermore, there is also the possibility that some zoonotic pathogens can spread to human populations and affect the health of smallholder families and communities.

In Cambodia, village animal health workers (VAHWs) have been officially recognized by law since 2001 and are required to formally register and undergo approved training. Training has historically focused on technical assistance and animal health services such as vaccination and treatments [7] [10] [11]. Use of VAHWs provides an accessible, market-based, animal health "treatment and reporting" service linked to livestock smallholders across Cambodia [7] [12]. Recent studies in Cambodia indicate that smallholder farmers use the VAHWs as their primary contact for heath related decisions [13]. Thus, increased veterinary extension to VAHWs and access to veterinary equipment, vaccines, and drugs may further increase VAHW-farmer engagement [7]. Moreover, increasing the knowledge of these animal health workers is critical for changing com- 
mon farmer habits and practices. Although most of Cambodian VAHWs previously received training on good hygienic practices, ensuring they consistently follow these practices can be challenging [14]. A study in China found that some village veterinarians did not apply consequent biosecurity measures (e.g. use of disinfectant or gloves) when handling sick animals which can pose a great threat to their own health or transmit the diseases in human and pig populations [14].

Several studies have been conducted on pig smallholder biosecurity in Vietnam [15], Indonesia [16], Uganda [9], Kenya [17], Madagascar [18], Central Africa [19], and India [20]. However, no information is available regarding knowledge and practices of pig biosecurity on pig smallholders and VAHWs in Cambodia. Thus, the objective of this study was to assess the knowledge and practices of biosecurity measures of smallholder farmers and VAHWs to reduce the risk of pig diseases in rural and peri-urban households in Cambodia.

\section{Material and Methods}

The research protocol and data collection tools were reviewed and approved by the Institutional Review Board at Kansas State University (IRB \#8899.1).

\subsection{Study Area}

The study areas comprised rural and peri-urban areas of Kampong Thom, Siem Reap, and Battambang province which were designated as within the zone of influence for the Feed the Future Innovation Lab for Livestock Systems in Cambodia (Figure 1).

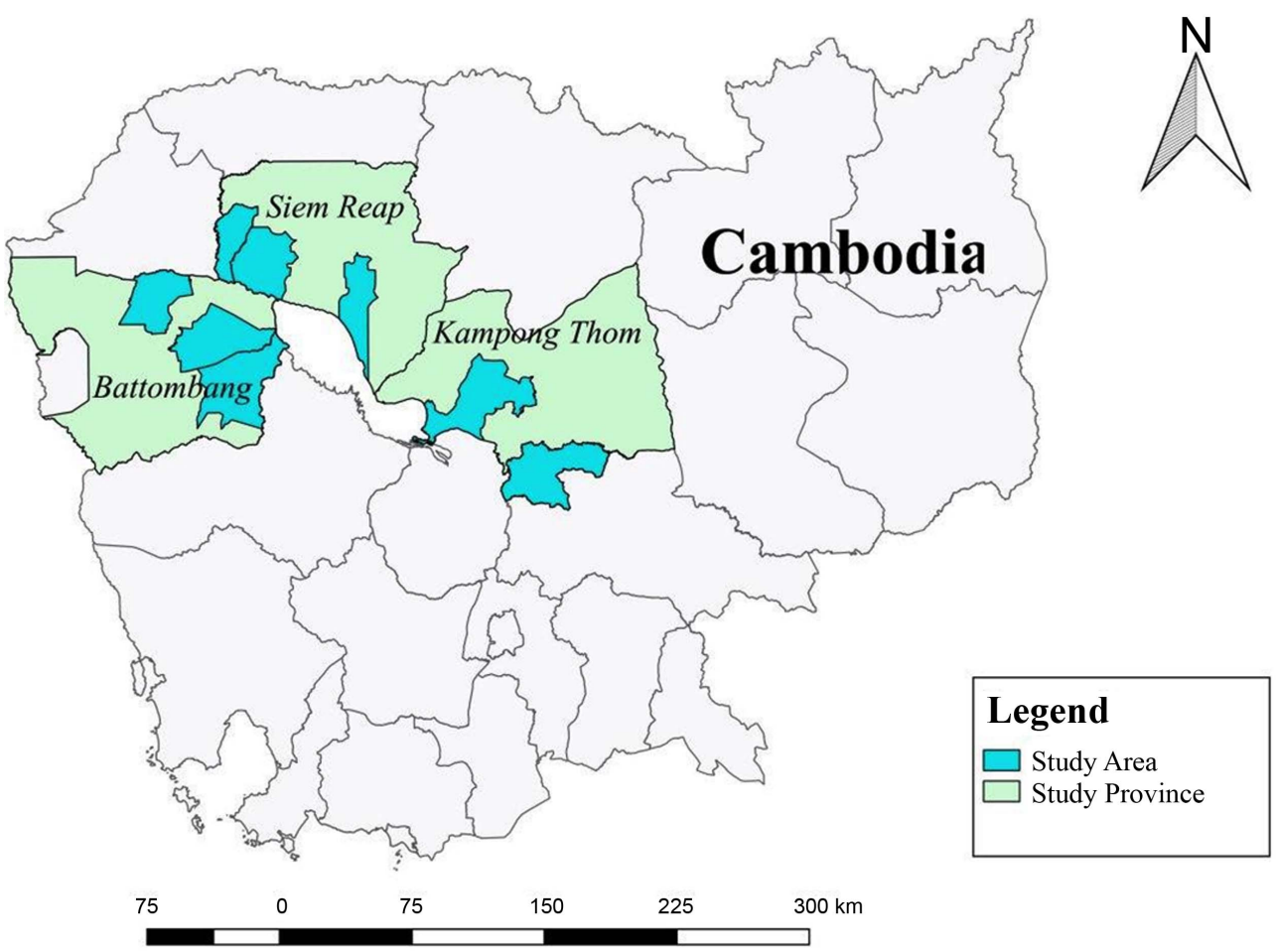

Figure 1. Map of study area. 


\subsection{Study Design and Data Collection}

Surveys were collected in over 10 months from December 2017 to September 2018. There were 225 pig farmers, 81 feed store owners, and 43 VAHWs and 3 -DVs enrolled in the surveys. The surveys were conducted under guidance of the district veterinarians in each target province. They facilitated farm selection and accompanied the Royal University of Agriculture (RUA) team on survey trips. Farmers, feed store owners, VAHWs, and DVs were chosen from two districts of Kampong Thom, and three districts in Battambang and Siem Reap. Selection of districts was based on information about the number of smallholder farms and density of pig populations in the study areas from reports from the Provincial Department of Agriculture, Forestry, and Fisheries and the Provincial Department of Animal Health and Production in each province. The survey was used to assess current practices and knowledge concerning feed and health management, as well as to identify gaps in disease management strategies. A census of surveys was performed by veterinary students and staff of faculty of veterinary medicine, RUA, Phnom Penh. Students and staff were trained in the use of the survey. The surveys were conducted via Kobotoolbox program on Ipads.

\subsection{Survey Tool Development}

A survey tool with three questionnaires was designed to investigate biosecurity knowledge and practices for different respondent groups: 1) farmers, 2) VAHWs and DVs, and 3) feed store owners. Each questionnaire consisted of a different set of questions designed to investigate the individual knowledge of respondent groups. The questionnaires were created in an online software developed by Harvard Humanitarian Initiative to serves as a "suite of tools for field data collection" (KoBoToolbox, Harvard Humanitarian Initiative) [21]. This software was chosen based upon a unique feature that allows surveys to be taken in offline mode; which allowed for data collection and storage in areas without an internet connection.

Survey questionnaires were developed in English and translated into Khmer (the local language) and orally administered-by university staff and students from the Royal University of Agriculture (RUA), Phnom Penh, Cambodia-to participants through a personal one-on-one interview technique. The survey was administered orally to gain more reflective answers, ensure the understanding of respondents on complex questions, and to maintain a quality control measure over response rate. Additionally, an observational assessment was conducted in feed stores, in order to examine the cleanliness and general settings of feed store environments.

\subsection{Farmer Survey}

A total of 225 farmers were interviewed in this study. Farmers were surveyed at their homes or pig barns. Farmers were surveyed to obtain data on feed re- 
sources, current diet practices, and knowledge concerning feed, biosecurity, and health management. Farmer surveys took about 40 minutes including the collection of the feed or ingredients, taking picture of the feed or ingredients, pig, pig barn area, and medicine used.

\subsection{Village Animal Health Worker or District Veterinarian Survey}

A total of 43 VAHWs and 3 DVs were interviewed in this study. The VAHWs or DVs surveys were conducted either at the home of the VAHWs or at the DVs' home. The VAHWs and DVs were surveyed to obtain data on services, medicinal tools, and knowledge on bio-security. VAHWs and DVs survey took about 50 minutes including taking picture of medicine, medicine tools, and medicine bag.

\subsection{Feed Store Surveys}

A total of 81 feed store owners were interviewed in this study. Feed store owners were surveyed at their stores. This survey included questions regarding feed or ingredient type and cost, veterinary drugs, and vaccines available at the store. Also, the status of store regarding hygiene management was assessed. Pictures of feed, ingredients, veterinary drugs, and vaccines were also taken with permission. Feed store surveys took about 30 minutes including sampling feed and ingredients.

\subsection{Statistical Analyses}

Results of the biosecurity portion of the surveys are presented here with information on other portions of the survey presented elsewhere. All data regarding current practices and knowledge concerning feed and health management were analyzed through descriptive statistics.

\section{Results}

\subsection{Farmer Surveys}

A total of 225 farmers were interviewed with $33 \%$ being male and $67 \%$ female (Table 1). In terms of pig ownership, $80 \%$ of the farmers owned sows, with $97 \%$ of them owning 10 or fewer. Interestingly, $50 \%$ of all farmers owned between 1 to 2 sows, and only $8 \%$ of farmers owned a boar. In total, $85 \%$ of farmers owned grow-finish pigs, with $38 \%$ of all farmers having 10 or less pigs, and $28 \%$ having 11 to 20 pigs. Only $10 \%$ of farmers had more than 30 grow-finish pigs. Most pigs (83\%) were of improved breeds with only $9 \%$ being local breeds and the remainder being a combination. There were no major differences in survey results between the three provinces.

Several concerning biosecurity areas were found in the farmer surveys (Table 2). Live boars from a boar man were used by $64 \%$ of the farmers for breeding with only $12 \%$ using artificial insemination (AI). Pig buyers come to the farm to buy the pigs in $99 \%$ of the cases and bring other pigs that were purchased from others with them $88 \%$ of the time. Farmers shared scales (48\%), cages (16\%), 
Table 1. Status of pig production of smallholders in provinces in Cambodia.

\begin{tabular}{|c|c|c|c|c|}
\hline \multirow{2}{*}{ Descriptions } & \multicolumn{3}{|c|}{ Provinces } & \multirow{2}{*}{ Overall } \\
\hline & Kampong Thom & Siem Reap & Battambang & \\
\hline \multicolumn{5}{|l|}{ 1) Gender } \\
\hline Male & $18 / 75(24)$ & $29 / 75(39)$ & $27 / 75(36)$ & $74 / 225(33)$ \\
\hline Female & $57 / 75(76)$ & $46 / 75(61)$ & $48 / 75(64)$ & $151 / 225(67)$ \\
\hline \multicolumn{5}{|l|}{ 2) Pig breed kept by farmers } \\
\hline Improved breed & $49 / 75(66)$ & $65 / 75(87)$ & $72 / 75(96)$ & $186 / 225(83)$ \\
\hline Local breed & $16 / 75(21)$ & $3 / 75(4)$ & $1 / 75(1)$ & $20 / 225(9)$ \\
\hline Both breed & $10 / 75(13)$ & $7 / 75(9)$ & $2 / 75(3)$ & $19 / 225(8)$ \\
\hline \multicolumn{5}{|c|}{ 3) Sows inventory kept by farmer (head) } \\
\hline 0 & $18 / 75(24)$ & $13 / 75(17)$ & $16 / 75(22)$ & $47 / 225(21)$ \\
\hline 1 & $28 / 75(37)$ & $19 / 75(25)$ & $21 / 75(28)$ & $68 / 225(30)$ \\
\hline 2 & $13 / 75(17)$ & $17 / 75(23)$ & 15/75 (20) & $45 / 225(20)$ \\
\hline 3 & $8 / 75(11)$ & $8 / 75(11)$ & $7 / 75(9)$ & $23 / 225(10)$ \\
\hline $4-10$ & $8 / 75(11)$ & $14 / 75(19)$ & $15 / 75(20)$ & $37 / 225(17)$ \\
\hline $10-<25$ & $0 / 75(0)$ & $4 / 75(5)$ & $1 / 75(1)$ & $5 / 225(2)$ \\
\hline \multicolumn{5}{|c|}{ 4) Boars inventory kept by farmers (head) } \\
\hline 0 & $72 / 75(96)$ & $66 / 75(88)$ & $70 / 75(93)$ & $208 / 225(92)$ \\
\hline 1 & $1 / 75(1)$ & $3 / 75(4)$ & $2 / 75(3)$ & $6 / 225(3)$ \\
\hline 2 & $0 / 75(0)$ & $1 / 75(1)$ & $0 / 75(0)$ & $1 / 225(0)$ \\
\hline 3 & $0 / 75(0)$ & $3 / 75(4)$ & $3 / 75(4)$ & $6 / 225(3)$ \\
\hline$<4-5$ & 2/75 (3) & $2 / 75(3)$ & $0 / 75(0)$ & $4 / 225(2)$ \\
\hline \multicolumn{5}{|l|}{$\begin{array}{l}\text { 5) Fattening pigs inventory kept by } \\
\text { farmers (head) }\end{array}$} \\
\hline 0 & $8 / 75(11)$ & $19 / 75(25)$ & $6 / 75(8)$ & $33 / 225(15)$ \\
\hline $1-10$ & $30 / 75(40)$ & $26 / 75(34)$ & $30 / 75(40)$ & $86 / 225(38)$ \\
\hline $11-20$ & $26 / 75(34)$ & $14 / 75(19)$ & $23 / 75(31)$ & $63 / 225(28)$ \\
\hline $21-30$ & $9 / 75(12)$ & $5 / 75(7)$ & $9 / 75(12)$ & $23 / 225(10)$ \\
\hline $31-<120$ & 2/75 (3) & $11 / 75(15)$ & $7 / 75(9)$ & $20 / 225(9)$ \\
\hline \multicolumn{5}{|l|}{ 6) Main pig sources } \\
\hline Own sows & $50 / 75(67)$ & $45 / 75(60)$ & $49 / 75(65)$ & $144 / 225(64)$ \\
\hline Buys directly from multiple sources & $20 / 75(27)$ & $25 / 75(34)$ & $13 / 75(18)$ & $58 / 225(26)$ \\
\hline Purchase from a contract farm & $4 / 75(5)$ & $1 / 75(1)$ & $7 / 75(9)$ & $12 / 225(5)$ \\
\hline Purchase from a pig buyer & $1 / 75(1)$ & $0 / 75(0)$ & $2 / 75(3)$ & $3 / 225(1)$ \\
\hline Received from NGO & $0 / 75(0)$ & $1 / 75(1)$ & $0 / 75(0)$ & $1 / 225(1)$ \\
\hline Other & $0 / 75(0)$ & $3 / 75(4)$ & $4 / 75(5)$ & $7 / 225$ (3) \\
\hline
\end{tabular}

Numbers in parenthesis are percentages. 
Table 2. Status of pig biosecurity management of smallholders in provinces in Cambodia.

\begin{tabular}{|c|c|c|c|c|}
\hline \multirow{2}{*}{ Descriptions } & \multicolumn{3}{|c|}{ Provinces } & \multirow{2}{*}{ Overall } \\
\hline & Kampong Thom & Siem Reap & Battambang & \\
\hline \multicolumn{5}{|l|}{$\begin{array}{l}\text { 1) People control by farmers to reduce } \\
\text { disease risks }\end{array}$} \\
\hline Neighbors come to see the pigs & $68 / 75(91)$ & $66 / 75(88)$ & $63 / 75(84)$ & $197 / 225(88)$ \\
\hline $\begin{array}{l}\text { Neighbors whom visit pigs own their own } \\
\text { pigs }\end{array}$ & $60 / 75(80)$ & $62 / 75(83)$ & $55 / 75(73)$ & $177 / 225(79)$ \\
\hline \multicolumn{5}{|l|}{$\begin{array}{l}\text { Farmer restrict access of other people to } \\
\text { the pig area }\end{array}$} \\
\hline No restrictions & $72 / 75(96)$ & $70 / 75(94)$ & $68 / 75(90)$ & $210 / 225(93)$ \\
\hline Visitors allowed with restrictions ${ }^{*}$ & $2 / 75(3)$ & $4 / 75(5)$ & $2 / 75(3)$ & $8 / 225(4)$ \\
\hline No visitors allowed & $1 / 75(1)$ & $1 / 75(1)$ & $5 / 75(7)$ & $7 / 225(3)$ \\
\hline \multicolumn{5}{|l|}{${ }^{\star}$ Types of restrictions } \\
\hline Change footwear & $0 / 75(0)$ & $1 / 75(1)$ & $0 / 75(0)$ & $1 / 225(1)$ \\
\hline Must not own or been around other pigs & $1 / 75(1)$ & $1 / 75(1)$ & $0 / 75(0)$ & $2 / 225(1)$ \\
\hline Disinfect shoes & $0 / 75(0)$ & $1 / 75(1)$ & $0 / 75(0)$ & $1 / 225(1)$ \\
\hline Must not own pigs & $0 / 75(0)$ & $1 / 75(1)$ & $0 / 75(0)$ & $1 / 225(1)$ \\
\hline Just allow as it is impolite to restrict & $1 / 75(1)$ & $0 / 75(0)$ & $0 / 75(0)$ & $1 / 225(1)$ \\
\hline Not allow strangers & $0 / 75(0)$ & $0 / 75(0)$ & $2 / 75(3)$ & $2 / 225(1)$ \\
\hline Person selling meat to the pig farm & $30 / 75(40)$ & $39 / 75(52)$ & $26 / 75(35)$ & $95 / 225(42)$ \\
\hline \multicolumn{5}{|l|}{ Pig selling and pig buyers } \\
\hline $\begin{array}{l}\text { Buyer comes to the farm and picks them } \\
\text { up }\end{array}$ & $75 / 75(100)$ & $74 / 75(99)$ & $74 / 75(99)$ & $223 / 225(99)$ \\
\hline Farmer takes pigs to the buyer & $0 / 75(0)$ & $1 / 75(1)$ & $1 / 75(1)$ & $2 / 225(1)$ \\
\hline Buyer purchase from other farms? & $70 / 75(93)$ & $63 / 75(84)$ & $65 / 75(87)$ & $198 / 225(88)$ \\
\hline Buyer brings a scale to the farm? & $6 / 75(8)$ & $5 / 75(7)$ & $9 / 75(12)$ & $20 / 225(9)$ \\
\hline \multicolumn{5}{|l|}{$\begin{array}{l}\text { 2) Waste feeding practices to pigs by } \\
\text { farmers }\end{array}$} \\
\hline Feeding restaurant waste to pigs & $3 / 75(4)$ & $4 / 75(5)$ & $7 / 75(9)$ & $14 / 225(6)$ \\
\hline $\begin{array}{l}\text { Delivery of restaurant waste to the pigs } \\
\text { farms }\end{array}$ & $3 / 75(4)$ & $4 / 75(5)$ & $7 / 75(9)$ & $14 / 225(6)$ \\
\hline $\begin{array}{l}\text { Restaurant waste cooked before feeding to } \\
\text { the pigs }\end{array}$ & $2 / 75(3)$ & $3 / 75(4)$ & $7 / 75(9)$ & $12 / 225(5)$ \\
\hline Feeding own kitchen waste to the pigs & $41 / 75(55)$ & $42 / 75(56)$ & $27 / 75(36)$ & $110 / 225(49)$ \\
\hline Kitchen waste contains meat scraps & $17 / 75(23)$ & $15 / 75(20)$ & $11 / 75(15)$ & $43 / 225(19)$ \\
\hline \multicolumn{5}{|l|}{$\begin{array}{l}\text { 3) Boars and semen management by } \\
\text { farmers }\end{array}$} \\
\hline \multicolumn{5}{|l|}{ Breeding sows } \\
\hline A boar man brings a boar & $44 / 75(59)$ & $44 / 75(59)$ & $57 / 75(76)$ & $145 / 225(64)$ \\
\hline Artificial insemination ${ }^{*}$ & $12 / 75(16)$ & $10 / 75(13)$ & $5 / 75(7)$ & $27 / 225(12)$ \\
\hline
\end{tabular}




\section{Continued}

\begin{tabular}{|c|c|c|c|c|}
\hline $\begin{array}{l}\text { Farmers own their boar and breeds sows to } \\
\text { others }\end{array}$ & $1 / 75(1)$ & $8 / 75(11)$ & $2 / 75(3)$ & $11 / 225(5)$ \\
\hline $\begin{array}{l}\text { Farmers own their boar and only use their } \\
\text { own sows }\end{array}$ & $0 / 75(0)$ & $1 / 75(1)$ & $1 / 75(1)$ & $2 / 225(1)$ \\
\hline Uses a boar from a neighbor & $4 / 75(5)$ & $0 / 75(0)$ & $1 / 75(1)$ & $5 / 225(2)$ \\
\hline \multicolumn{5}{|l|}{${ }^{\star}$ Who does the artificial insemination? } \\
\hline Boar owner & $11 / 12(92)$ & $5 / 10(50)$ & $1 / 10(20)$ & $17 / 27(63)$ \\
\hline Farmer themselves & $1 / 12(8)$ & $5 / 10(50)$ & $2 / 10(40)$ & $8 / 27(30)$ \\
\hline Village animal health workers & $0 / 12(0)$ & $0 / 10(0)$ & $2 / 10(40)$ & $2 / 27(7)$ \\
\hline \multicolumn{5}{|l|}{ 4) Sharing equipment by farmers } \\
\hline Scale & $35 / 75(47)$ & $28 / 75(37)$ & $46 / 75(61)$ & $109 / 225(48)$ \\
\hline Pig's cage & $15 / 75(20)$ & $17 / 75(23)$ & $3 / 75(4)$ & $35 / 225(16)$ \\
\hline Cart to move the feed & $7 / 75(9)$ & $13 / 75(17)$ & $3 / 75(4)$ & $23 / 225(10)$ \\
\hline Pig lifting stick & $10 / 75(14)$ & $6 / 75(8)$ & $1 / 75(1)$ & $17 / 225(8)$ \\
\hline Teeth clipper/tail docker & $0 / 75(0)$ & $1 / 75(1)$ & $6 / 75(8)$ & $7 / 225(3)$ \\
\hline Other & $0 / 75(0)$ & $1 / 75(1)$ & $0 / 75(0)$ & $1 / 225(1)$ \\
\hline \multicolumn{5}{|l|}{ 5) Own livestock besides pigs by farmers } \\
\hline Chickens & $69 / 75(92)$ & $72 / 75(96)$ & $61 / 75(81)$ & $202 / 225(90)$ \\
\hline Ducks & $28 / 75(37)$ & $45 / 75(60)$ & $35 / 75(47)$ & $108 / 225(48)$ \\
\hline Cattle & $25 / 75(33)$ & $40 / 75(53)$ & $21 / 75(28)$ & $86 / 225(38)$ \\
\hline Geese & 6/75 (8) & $1 / 75(1)$ & $4 / 75(5)$ & $11 / 225(5)$ \\
\hline Buffalos & $1 / 75(1)$ & $0 / 75(0)$ & $0 / 75(0)$ & $1 / 225(1)$ \\
\hline Goats & $0 / 75(0)$ & $0 / 75(0)$ & $1 / 75(1)$ & $1 / 225(1)$ \\
\hline Other & $2 / 75(3)$ & $6 / 75(8)$ & $0 / 75(0)$ & $8 / 225(4)$ \\
\hline \multicolumn{5}{|l|}{ 6) Manure management } \\
\hline Not collected or managed & $50 / 75(67)$ & $60 / 75(81)$ & $59 / 75(79)$ & $169 / 225(75)$ \\
\hline Collected and fertilize crops/vegetables & $24 / 75(32)$ & $7 / 75(9)$ & $16 / 75(21)$ & $47 / 225(21)$ \\
\hline Use for Biogas system & $0 / 75(0)$ & 7/75 (9) & $0 / 75(0)$ & $7 / 225(3)$ \\
\hline Other & $1 / 75(1)$ & $1 / 75(1)$ & $0 / 75(0)$ & $2 / 225(1)$ \\
\hline
\end{tabular}

Numbers in parenthesis are percentages.

trucks or carts (10\%), or other supplies. Almost all of the farmers (93\%) allowed visitors near their pigs without restrictions and $88 \%$ said their neighbors come to see their pigs with $79 \%$ of those neighbors also having pigs. Kitchen waste was fed by $49 \%$ of the farmers with meat scraps included in the kitchen waste by $19 \%$ of them. Farmers also indicated that people come to the farm to sell meat ( $42 \%$ of those surveyed). Manure management was also an issue with manure not being collected or managed by $75 \%$ of farms. Keeping livestock with the pigs also was found to be an issue with $90 \%$ of farmers also having chickens, $48 \%$ having ducks, $38 \%$ with cattle, and less than $5 \%$ having others animals. 


\subsection{Village Animal Health Worker and District Veterinarian Surveys}

A total of 46 village animal health workers and district veterinarians were interviewed with $83 \%$ male and $17 \%$ female (Table 3 ). Twenty percent of them had

Table 3. Biosecurity practices by village animal health workers in Cambodia.

\begin{tabular}{|c|c|}
\hline Descriptions & Overall \\
\hline \multicolumn{2}{|l|}{ 1) Gender } \\
\hline Male & $38 / 46(83)$ \\
\hline Female & $8 / 46(17)$ \\
\hline \multicolumn{2}{|l|}{ 2) Experience of VAHWs } \\
\hline $0-10$ & $9 / 46(20)$ \\
\hline $11-20$ & $23 / 46(50)$ \\
\hline $21->30$ & $14 / 46(30)$ \\
\hline \multicolumn{2}{|l|}{ 3) Mode of transportation of VAHWs } \\
\hline Motorcycle & $46 / 46(100)$ \\
\hline Bike cycle & $7 / 46(15)$ \\
\hline Walk & $8 / 46(17)$ \\
\hline \multicolumn{2}{|l|}{ 4) Order of visiting pig farm of VAHWs } \\
\hline Least sick to most sick & $4 / 46(9)$ \\
\hline Most urgent first & $23 / 46(50)$ \\
\hline Farms that are closer to minimized the travel between farms & $3 / 46(6)$ \\
\hline Whenever calls first is visited first & $16 / 46(35)$ \\
\hline \multicolumn{2}{|l|}{ 5) Biosecurity practiced by VAHWs when visit farm to farm } \\
\hline No biosecurity & $13 / 46(28)$ \\
\hline Wash hands between farms & $40 / 46(87)$ \\
\hline Disinfect shoes between farms & $10 / 46(22)$ \\
\hline Change clothes/shoes between farms & $5 / 46(11)$ \\
\hline Wash vehicle between farms & $1 / 46(2)$ \\
\hline Other & $3 / 46(7)$ \\
\hline \multicolumn{2}{|l|}{ 6) Needle use by VAHWs } \\
\hline Needle reuse when get dull by the VAHWs & $25 / 46(54)$ \\
\hline \multicolumn{2}{|l|}{ Ways to clean reusable needles by VAHWs } \\
\hline Alcohol & $2 / 41(5)$ \\
\hline Boil in water & $34 / 41(83)$ \\
\hline Other & $5 / 41(12)$ \\
\hline \multicolumn{2}{|l|}{ Needle change during pig treatment by VAHWs } \\
\hline Between farms & 20/41 (49) \\
\hline Between pigs & $16 / 41(39)$ \\
\hline When needle gets damaged or broken & $5 / 41(12)$ \\
\hline
\end{tabular}

Data was obtained from VAHWs and DVs in Kampong Thom, Siem Reap, and Battambang province. Numbers in parenthesis are percentages. 
10 years of experience or less. Fifty percent of them had 10 to 20 years of experience, while $30 \%$ had more than 20 years of experience. All respondents used motorcycles for pig service calls. Less than $20 \%$ of respondents reported that they will walk or ride their bikes when the pig service calls are close in proximity to their houses. VAHWs utilized various techniques for setting their schedules for farm visits. Fifty percent of them prioritized urgent issues first, while 35\% visit farms in the order that the request for visit was received. Less than $10 \%$ of them visit farms in order of least to most sick pigs or by distance between farms (closest farm first).

Twenty-eight percent of VAHWs or DVs stated they went to the pig farm without practicing any biosecurity. Hand washing was common with $87 \%$ of VAHWs indicating that they washed hands between farms. Fifty-four percent of VAHWs or DVs used reusable needles. Forty-nine percent of VAHWs or DVs changed needle between farms and 39\% changed needles between pigs. Some of them $(12 \%)$ used reusable needle until the needle gets damaged or broken during pig treatment.

\subsection{Feed Store Surveys}

Cleanliness was an issue in the feed stores with $35 \%$ having dirty floors that hadn't been swept recently and $28 \%$ having fecal matter present (Table 4 ). Spilled feed ingredients on the floor were found in $48 \%$ of stores and there was evidence of rodents in $74 \%$ of stores. Other animals in the feed store were also a concern with $92 \%$ having live chickens in the store and 58\% having other live birds or bird feces in the store. Thirty-eight percent of store owners indicated that they or their workers had pigs on their own farm.

Table 4. Status of store in feed store in Cambodia.

\begin{tabular}{lc}
\hline \multicolumn{1}{c}{ Descriptions } & Overall \\
\hline 1) Gender & $38 / 81(47)$ \\
Male & $43 / 81(53)$ \\
Female & $51 / 81(63)$ \\
2) Sell veterinary medications & \\
3) Handle veterinary medications & $33 / 51(65)$ \\
In cabinet that can be in sunlight for at least part of the day & $18 / 51(35)$ \\
In cabinet that is never in the sunlight & \\
4) Hygiene and management of the store & $31 / 81(38)$ \\
Store owners has pigs on their own farm & $6 / 81(7)$ \\
Floor of the store get wet & $28 / 81(35)$ \\
Floor looks like it has been swept recently & $23 / 81(28)$ \\
Having fecal material in front of the store & $39 / 81(48)$ \\
Loose or spilled feed ingredients on the floor & $60 / 81(74)$ \\
Evidence of rodents in the store &
\end{tabular}




\section{Continued}

\begin{tabular}{lc}
\hline Evidence of live birds and bird faces in the store & $47 / 81(58)$ \\
Evidence of live farm animals at the store & \\
Chickens & $22 / 24(92)$ \\
Dogs & $2 / 24(8)$ \\
\hline
\end{tabular}

Data was obtained from VAHWs and DVs in Kampong Thom, Siem Reap, and Battambang province. Numbers in parenthesis are percentages.

\section{Discussion}

Pigs make an important contribution to the livelihoods of urban, peri-urban, and rural households Cambodia, but many households face external constraints on their pig production, such as diseases and low revenues, which may have a negative impact on their livelihoods [22]. This paper presents the biosecurity knowledge and practices of Cambodia pig smallholder farmers and VAHWs collected through in-person surveys. The biosecurity knowledge and practices measures covered in this study included introduction of new pigs and breeding, instruments or equipment, other species present in the farms, waste feeding, manure, and visitors and their vehicles management, which are all part of compliance recommendations for smallholder farmers by [23]. Several pig biosecurity concerns were found from farmer surveys, including using natural boar, sharing pig equipment, managing other livestock, feeding kitchen waste, handling manure, and control of visitors (village animal health workers, boar owners, pig buyers, neighbors, and pig meat sellers).

Adding new pigs, either from single or multi sources, to the farm without a quarantine period or sanitation practice, contributes the greatest risk to the health of the pigs in a pig operation [24]. This study found that $26 \%$ of farmers acquiring pigs from multiple sources. Similar results were found by a study in Madagascar [18]. An even greater percent of farmers in Cameroon (59\%) indicated purchasing pigs from multi sources [25]. When surveyed, very few farmers indicated that pigs are purchased or received from a contract farm. This is a missed opportunity, as contract farms may have stronger disease control programs, simply based upon infrastructure and technical capacity. They also can provide pigs from a single source over time to provide a more consistent disease status. Few interviewed farmers purchased pigs from a pig buyer, which is positive, due to the fact that often these pigs are from unknown origins and may travel through multiple farms before being purchased.

Although more farmers (64\%) preferred to keep pigs from their own sows, the respondents indicated that $64 \%$ use live boars for breeding sows, with only $12 \%$ using AI. Using natural mating by unknown boars or wild boars not only leads to higher mortality rates of newborn piglets [26], but also transmits diseases between sows and boars, which can lead to large outbreaks of diseases among pig populations [25]. It is well documented that introduction of semen or animals from different herds increases the risk of disease introduction to pig farms [27] 
[28] [29]. Exchange of animals among farms is one of the most rapid ways for disease dissemination, because an animal may appear to be healthy while it may actually be experiencing chronic disease or within incubation time-frames for microbial pathogens [25]. Introducing new animals into a farm can increase the likelihood of disease transmission from new animals to animals already on the farm. For instance, pigs with chronic forms of African Swine Fever (ASF) can live for several months [30]; while living in a chronic stage, these pigs will pose a major hazard for pig farms, as the virus will be shed via their secretions and excretions. Therefore, the widespread practice of utilizing natural breeding with boars, which was observed among farmers in the study, is of major concern. An alternative solution for reproduction could be use of AI, which is already practiced on a limited number of farms surveyed in this study. However, limited availability, lack of expertise, and cost of AI service may limit AI utilization by farmers in the present areas of this study. Nevertheless, those farmers should pay attention to biosecurity measure whether they practice doing AI by themselves or use service from boar owners and VAHWs. Disease can be transmitted from semen if inappropriate hygiene is used during semen collection and distribution. Boars should be routinely screened for infections known to be spread by semen through boar man or service providers [23].

Equipment used by pig farmers must be considered as potentially contaminated fomites [23]. Thus, sharing of equipment, even valuable equipment, between farms should be minimized [24]. Any equipment, including veterinary equipment, slurry spreaders, etc. moving onto or from premises must be thoroughly cleaned and disinfected. This study found that farmers shared mostly scales (48\%) and cages (16\%). Although shared to a lesser extent, trucks or carts (10\%), and other supplies (teeth clipper/tail docker) were also shared without applying good sanitation practices. This practice could spread pig diseases from one farm to another, or from one pig to another on a given farm. Similar study results have been reported by [25] specifically for production tools and equipment used with a piggery. Scales or cages were primarily shared by farmers in the study when pigs were at the age of being slaughtered, which could transmit pathogens to other pigs from urine and faeces contaminating the scale. This suggest that farmers should clean or disinfect equipment before it is moved to another farm. Applying good sanitation is the one way to reduce disease transmission from use of pig equipment [24].

This study found that almost all of the pig farmers kept chickens, and nearly half of them kept ducks, cattle, geese, goat, and pets, which is a serious biosecurity problem since cross contamination of pathogens between different species has been previously demonstrated [23] [31] [32]. Similar finding have been reported by [16] [25]. Although pigs were confined in the present study, some diseases/pathogens that can be transmitted from other animals to pigs or vice versa include: Bordetella spp., avian tuberculosis, Salmonella spp. classical swine fever, PRRSV, IAV, and TGE, and avian influenza [24] [31] from birds to pigs; 
Salmonella Typhimurium between pigs, poultry and ruminants [32]; classical swine fever [33]; Aujesky's disease [34] from wild boar to pigs and pig dysentery, brucellosis, Pasteurella, leptospirosis and toxoplasmosis [24] from dogs or cats to pigs.

Livestock manure is a valuable fertilizer that may contribute to enhanced food security by improving soils and increasing crop yields, when managed properly [35]. In Cambodia, pig manure is commonly used to fertilize rice, vegetables, and sell, but it is also discharged into the environment close to the pig barn [36]. The practice of dumping pig manure is more common in households with a lower socio-economic index [37]. In this study, two-thirds of the farmers indicated that manure was not being collected or managed. However, of the farmers who do collected and manage manure, only $21 \%$ of them utilize it to fertilize crops; while 3\% used manure for biogas production. Similar finding has been reported with non-biogas farms in Vietnam [37]. However, studies by [18] [36] reported that, on smallholder farms, one-half of the pig manure is discarded from the pig barn. In Cambodia, manure management practices vary by region and farmer training. Farmer often allows the pig manure to run out of the pig barn into a pond, canal, or rice field. Consequently, poor manure management by urban and peri-urban households may pose a public health threat and an environmental hazard when the pig manure is dumped in the environment [23] [36]. The poor management of the pig manure in Cambodia may due to manure application practices, low transportation availability, and socio-economic factors [36]. These findings support the theory that resource-poor livestock keepers might have limited means to invest in the equipment necessary for proper manure disposal [38]. Low use of manure to fertilize the crops in the present study is in agreement with the previous findings. Biogas is economically viable and sustainable for rural household and as well as safe for resources and provide fertilizer [39]. Cambodian farmers normally used pig manure to make gas used in household for cooking and lighting. However, we found few farmers have implement this practice.

This study found $49 \%$ of the farmers fed kitchen waste with $19 \%$ feeding kitchen waste contained meat scraps and $6 \%$ feeding restaurant waste. One concern related to feeding food waste to pigs is the potential to transmit disease to the pigs, especially infectious diseases including classical swine fever, foot and mouth disease, ASF, and pig vesicular disease. Other pathogens of concern that could spread to humans are Salmonella, Campylobacter, Trichinella, and Toxoplasma. Therefore, food waste to be fed to pigs must be heat treated [23] [24] [25]. Diseases may be spread to other livestock or humans if pigs consume contaminated meat in improperly treated food waste [24]. Although restaurant waste was cooked by most farmers, cooking temperature is not well monitored and management of waste delivery before cooking, such as delivery container, vehicle, and personnel needs improved sanitation. As observed, restaurant waste was delivered to the pig area where chickens and ducks could be exposed to the waste before the waste was cooked. Those animals roamed around the pig barn 
and sometime get close to the pigs. Thus, they could transfer pathogens to the pigs. Feeding kitchen waste is common for smallholder farmers in Cambodia, similar to practices of small farmers in Cameroon, Central Africa [25]. Thus, countries where kitchen waste feeding is practiced need increased education on proper cooking and management for farmers.

Livestock haulers (buyers and transporters), livestock-owning neighbors, workers or others that keep pigs of their own, along with processing crews, and veterinarians are groups that pose a high-risk for bringing disease onto pig farms. Presence of these people in the pig farm poses a higher risk for disease introduction if biosecurity is not taking place [23] [24]. These farm visitors can transport pathogens on footwear, clothing, hands, or equipment. For instance, they can carry viruses on their nasal mucosae (nasal carriers) without being infected, and can also be infected by and shed pathogens when they are sick or asymptomatic carriers [23]. This study found that almost all of the farmers (93\%) allowed visitors near their pigs without restrictions. In a similar study in Vietnam [15]. Furthermore, Ninety-nine percent of the farmers allowed the traders/pig buyers to come into the pen with their pigs and $88 \%$ of those buyers travel to different farms on the same day, which could lead to pig disease exchange from one to another farm and as well as their vehicles and pig holdings. It is in agreement with data reported by [40]; livestock traders in Cambodia carried a high risk of spreading disease. This suggests that education of livestock traders about preventing disease spread should be a priority in Cambodia. Contrarily, trader/pig buyers were not frequent farm visitors in Madagascar with only $33 \%$ of farmers allowing them to visit their pigs [18]. The difference between studies may be differences in farmer traditions as pig farmers in Madagascar prefer to sell their pigs to the market rather than to traders or other pig farmers while Cambodian farmers rely on traders. Additionally, $88 \%$ of farmers stated their neighbors come to see their pigs with $79 \%$ of those neighbors also having pigs. In Madagascar, $31 \%$ of pig farmers allowed other pig farmers to visit their farms and $47 \%$ of them allowed family or friends. VAHWs are allowed to enter the pig barn without any restriction. However, most of them practiced good sanitation while $28 \%$ of them did not practice any sanitation procedures. A relatively high percentage (42\%) of farmers indicated that people come to the farm to sell meat. A similar percentage was reported by a study in Madagascar by [18]. Delivery of raw meat to farms is a concern because of the potential pathogens present in raw meat and the person transporting the meat moves from farm to farm and may serve transfer disease on their shoes and transportation vehicle. Biosecurity measures include showering with a complete change of boots and coverall, and use of gloves is often recommended for pig farms. These practices are often implemented on high or medium economic-farmers which is mainly semi-commercial and commercial farms [24]. It is likely for smallholders such as those in the present study will not implement these practices. Alternatively, farmers can do other biosecurity steps, such as use of caution, no visitor signs, fencing, changes of shoes, and other means of limiting visitor entry. 
Limited knowledge and poor biosecurity practices of VAHWs or DVs were found in this study including physical service material management, and prioritization in visiting pig farms. All of VAHWs or DVs used motorcycle for traveling for the pig service, but only few of them washed vehicles between farms and none used disinfectants. Disinfectants cost money and can be corrosive, but washing vehicle without using disinfectants may increase the risk of vehicle contamination by creating an infectious slurry puddle of run-off [40]. Furthermore, vehicles can become contaminated and can carry disease when manure containing disease agents adheres to vehicle tires or bodywork [23]. Some important pathogens such as African Swine Fever, Porcine Epidemic Diarrhoea, Actinobacillus pleuropneumoniae, TGE, and Streptococcus suis can be shed in the faeces of infected animals at extremely high rates and they spread easily and quickly via contaminated vehicles [23]. People including workers, visitors, and service providers can transport pathogens on footwear, clothing, and hands [23] [24]. Consequently, transmission may occur through urine and faeces from infected animals on footwear and clothing as has been proven through experiments with several pathogens, including $E$. coli [42] and classical swine fever virus [41]. This study found that VAHWs or DVs practiced some biosecurity measures with $87 \%$ washing hands, $22 \%$ disinfecting shoes, and $11 \%$ changing clothes and shoes between farms. Although, a majority of VAHWs or DVs practiced hand washing, and some of them disinfect shoes and change clothes or shoes, these practices alone remain insufficient as some pathogens can survive without disinfection. Combination of practices is needed to reduce contaminated pathogens. Twenty-eight percent of VAHWs stated they went to the pig farm without practicing any biosecurity. This poor practice could lead to transmission of pig diseases from one to another farm during the day they visit. [7] reported that about $50 \%$ of VAHWs visit livestock (mainly cattle) more than once a day. The combination pig and cattle service made by the VAHWs during the day could explain this hypothesis. [14] reported that ensuring VAHWs consistently follow good practices can be challenging, although they had received training on good hygienic practices. Similar study in China found that some village veterinarians did not apply consequent biosecurity measures (e.g. use of disinfectant or gloves) when handling sick animals [14].

About $50 \%$ of VAHWs or DVs changed needle between farms; while $39 \%$ of them changed needles between pigs. Good biosecurity recommendation suggests all administered treatment needles should be single use and if not applicable, all multiple needle use should be confined to a single needle per litter or single needle per pen [43]. Reuse of needles poses a special risk of transferring infection from one group of animals to another [43]. However, half of VAHWs or DVs in the present study still use reusable needles, and some of them used the needle until it was damaged or broken during pig treatment. For those using reusable needles, VAHWs or DVs have been mainly boiled them in hot water or cleaning with alcohol. However, insuring proper boiling and alcohol cleaning 
can be challenging. Fifty percent of VAHWs or DVs visited the pig farm with most urgent problems first with only a few visiting pig farms in order from least to most sick pigs. This indicated poor understanding of biosecurity and their role in transferring pathogens from sick to healthy pigs. The farmer survey indicated that $41 \%$ of farmers called VAHW when their pigs were sick, and $16 \%$ called the VAHW when the pigs were very sick and when self-medication was not effective (data was not shown). The results of this study on use of VAHW by farmers are consistent with a previous study in Cambodia by [13].

Feed or ingredients can serve as a possible source of pathogens (viruses and bacteria) as well as mycotoxins [24]. Those pathogens can contaminate the feed or ingredients when there is unclean loading of the feed bag, dirty floor, and present of urine or fecal material from the rodents, birds, pets, and livestock. This study found $35 \%$ of feed store had dirty floors that hadn't been swept recently, and $28 \%$ had fecal material present in front of the store. There was evidence of rodents in $74 \%$ of stores. Other animals, mainly live chickens, were present with $92 \%$ and other live birds or bird feces present in $58 \%$ of stores. It is documented in Prakas of MAFF Cambodia with article No 14 that stores that are unhygienic, inappropriate to technical standards, or carrying pathogens that are harmful to humans' and animal's health and animal production will be challenged to terminate the business, however, it is likely that monitoring of stores has not been implemented yet. The problem is when the contaminated feed or ingredients delivered to the pig farms will transmit some important diseases if good sanitation is not applied. It is recommended that farm-owned vehicle must be thoroughly cleaned, washed, and disinfected and as well as biosecurity practiced by the driver prior to picking up the feed [44]. We found that $84 \%$ of farmers picked up feed or ingredients from the feed store themselves, while $15 \%$ received deliveries by the feed store owner (data not shown) without any applying good sanitation on vehicles. Similar finding in Madagascar has been report by [18].

\section{Conclusion}

Several pig biosecurity guidelines were not followed or well understood by farmers. Specific concerning practices included using natural boar, sharing pig equipment, feeding waste, managing other livestock, handling manure, and unrestricted access by visitors (VAHWs or DVs, boar owners, pig buyers, neighbors, and meat sellers). Thus, education of pig smallholder farmers and VAHWs on pig biosecurity is needed for improving pig production, economics value, and livelihood of smallholder farmers in Cambodia.

\section{Acknowledgements}

This work was funded in whole by the United States Agency for International Development (USAID) Bureau for Food Security under Agreements \#AID-OAA-L-15-00003 as part of Feed the Future Innovation Lab for Livestock 
Systems. We are also thankful to the local authorities, farmers, village animal health workers, and the feed store owners which collaborated with us; and senior staff and junior students from the Faculty of Veterinary Medicine, Royal University of Agriculture which contributed to collecting survey data.

\section{Conflicts of Interest}

Any opinions, findings, conclusions, or recommendations expressed here are those of the authors alone. The authors declare no conflicts of interest regarding the publication of this paper.

\section{References}

[1] Ministry of Agriculture, Forestry, and Fisheries (2015) Agriculture Sector Strategic Development Plan 2014-2018. http://extwprlegs1.fao.org/docs/pdf/cam155661.pdf

[2] FAO (Food and Agriculture Organization of the United Nations) (2005) Livestock Sector Brief. Livestock Information, Sector Analysis and Policy Branch, AGAL. http://www.fao.org/ag/againfo/resources/en/publications/sector briefs/lsb TZA.pdf

[3] Samkol, P., Borin, K. and Sovann, S. (2006) Pig Systems in Southeast Asia-The Case of Cambodia: Pig Systems in Asia and the Pacific: How Can Research and Development Enhance Benefits to the Poor? Proceedings of a Regional Conference, Bangkok, 23-24 November 2006, 34-42.

[4] Huynh, T., Aarnink, A., Drucker, A., Verstegen, M., Huynh, T., Aarnink, A.J., Drucker, W. and Verstegen, M.W. (2007) Pig Production in Cambodia, Laos, Philippines, and Vietnam: A Review.

https://www.scienceopen.com/document?vid=2c7f2a9c-e100-4be7-8915-2267ab266 ae6

[5] Dione, M.M., Ouma, E.A., Roesel, K., Kungu, J., Lule, P. and Pezo, D. (2014) Participatory Assessment of Animal Health and Husbandry Practices in Smallholder Pig Production Systems in Three High Poverty Districts in Uganda. Preventive Veterinary Medicine, 117, 565-576. https://doi.org/10.1016/j.prevetmed.2014.10.012

[6] Riedel, S., Schiborra, A., Huelsebusch, C., Huanming, M. and Schlecht, E. (2012) Opportunities and Challenges for Smallholder Pig Production Systems in a Mountainous Region of Xishuangbanna, Yunnan Province, China. Tropical Animal Health and Production, 44, 1971-1980. https://doi.org/10.1007/s11250-012-0166-5

[7] Stratton, J., Toribio, J.-a.L.M.L., Suon, S., Young, J.R., Cowled, B. and Windsor, P.A. (2017) Are Village Animal Health Workers Able to Assist in Strengthening Transboundary Animal Disease Control in Cambodia? Transboundary and Emerging Diseases, 64, 634-643. https://doi.org/10.1111/tbed.12432

[8] Adenuga, A., Mateus, A., Ty, C., Borin, K., Holl, D., San, S., Duggan, V., Clark, M., Smith, G.J.D., Coker, R., Vaughn, A. and Rudge, J.W. (2018) Seroprevalence and Awareness of Porcine Cysticercosis across Different Pig Production Systems in South-Central Cambodia. Parasite Epidemiology and Control, 3, 1-12. https://doi.org/10.1016/j.parepi.2017.10.003

[9] Dione, M., Masembe, C., Akol, J., Amia, W., Kungu, J., Lee, H.S. and Wieland, B. (2018) The Importance of On-Farm Biosecurity: Sero-Prevalence and Risk Factors of Bacterial and Viral Pathogens in Smallholder Pig Systems in Uganda. Acta Tropica, 187, 214-221. https://doi.org/10.1016/j.actatropica.2018.06.025

[10] Calba, C., Ponsich, A., Nam, S., Collineau, L., Min, S., Thonnat, J. and Goutard, F.L. 
(2014) Development of a Participatory Tool for the Evaluation of Village Animal Health Workers in Cambodia. Acta Tropica, 134, 17-28. https://doi.org/10.1016/j.actatropica.2014.02.013

[11] Burgos, J.H. and Thieme, O. (2008) Poultry, HPAI and Livelihoods in Cambodia-A Review.

http://agris.fao.org/agris-search/search.do?recordID=GB2012111799

[12] Bhandari, D.P., Wollen, T.S. and Lohani, M.N. (2011) Preventing Highly Pathogenic Avian Influenza (HPAI) at the Rural Community Level: A Case Study from Cambodia. Tropical Animal Health and Production, 43, 1071-1073. https://doi.org/10.1007/s11250-011-9828-y

[13] Tornimbene, B., Chhim, V., Sorn, S., Drew, T.W. and Guitian, J. (2014) Knowledge, Attitudes and Practices of Cambodian Pig Farmers in Relation to Porcine Reproductive and Respiratory Syndrome (PRRS). Preventive Veterinary Medicine, 116, 252-267. https://doi.org/10.1016/j.prevetmed.2013.12.009

[14] Jeffrey, G., Delia, G., Fred, U., Lucy, L., Rainer, A., Korapin, T., Khieu, B., Yang, G., Winda, D., Mai, V.H. and Amanda, W. (2014) Increasing Awareness of Zoonotic Diseases among Health Workers and Rural Communities in Southeast Asia. ILRI (aka ILCA and ILRAD).

[15] Barot, M. (2017) Biosecurity and Disease Control Perceptions and Practices of Vietnamese Smallholder Pig Farmers. MSc Thesis, University of Sydney, Sydney.

[16] Leslie, E.E.C., Geong, M., Abdurrahman, M., Ward, M.P. and Toribio, J.-A.L.M.L. (2015) A Description of Smallholder Pig Production Systems in Eastern Indonesia. Preventive Veterinary Medicine, 118, 319-327. https://doi.org/10.1016/j.prevetmed.2014.12.006

[17] Nantima, N., Davies, J., Dione, M., Ocaido, M., Okoth, E., Mugisha, A. and Bishop, R. (2016) Enhancing Knowledge and Awareness of Biosecurity Practices for Control of African Pig Fever among Smallholder Pig Farmers in Four Districts along the Kenya-Uganda Border. Tropical Animal Health and Production, 48, 727-734. https://doi.org/10.1007/s11250-016-1015-8

[18] Costard, S., Porphyre, V., Messad, S., Rakotondrahanta, S., Vidon, H., Roger, F. and Pfeiffer, D.U. (2009) Multivariate Analysis of Management and Biosecurity Practices in Smallholder Pig Farms in Madagascar. Preventive Veterinary Medicine, 92, 199-209. https://doi.org/10.1016/j.prevetmed.2009.08.010

[19] Kouam, M.K. and Moussala, J.O. (2018) Assessment of Factors Influencing the Implementation of Biosecurity Measures on Pig Farms in the Western Highlands of Cameroon (Central Africa). Veterinary Medicine International, 2018, Article ID: 9173646. https://doi.org/10.1155/2018/9173646

[20] Rajesh, J.B., Rajkhowa, S., Dimri, U., Prasad, H.L.D., Chethan, G.S. and Zosangpuii (2019) Health Related Management Practices at Pig Farms of North East India. Journal of AgriSearch, 6, 60-63. https://doi.org/10.21921/jas.v6i1.14923

[21] KoBoToolbox (2019) Simple, Robust and Powerful Tools for Data Collection. https://www.kobotoolbox.org

[22] Ström, G., Djurfeldt, A.A., Boqvist, S., Albihn, A., Sokerya, S., San, S., Davun, H. and Magnusson, U. (2017) Urban and Peri-Urban Family-Based Pig-Keeping in Cambodia: Characteristics, Management and Perceived Benefits and Constraints. PLoS ONE, 12, e0182247. https://doi.org/10.1371/journal.pone.0182247

[23] Food and Agriculture Organization of the United Nations/World Organisation for Animal Health/World Bank (2010) Good Practices for Biosecurity in the Pig Sector-Issues and Options in Developing and Transition Countries. FAO Animal 
Production and Health Paper No. 169. FAO, Rome.

[24] Ramirez, A. and Zaabel, P. (2012) Pig Biological Risk Management. Veterinary Diagnostic and Production Animal Medicine Publications, 1-61.

[25] Kouam, M.K., Jacouba, M. and Moussala, J.O. (2020) Management and Biosecurity Practices on Pig Farms in the Western Highlands of Cameroon (Central Africa). Veterinary Medicine and Science, 6, 82-91. https://doi.org/10.1002/vms3.211

[26] Sokchea, H., Thu Hong, T.T., Ngoan, L.D. and Borin, K. (2018) Pig Production System of Ethnic Group in Ratanakiri. Journal of Veterinary and Animal Research, 1,103 .

[27] Hege, R., Zimmermann, W., Scheidegger, R. and Stärk, K.D.C. (2002) Incidence of Reinfections with Mycoplasma hyopneumoniae and Actinobacillus pleuropneumoniae in Pig Farms Located in Respiratory-Disease-Free Regions of Switzerland-Identification and Quantification of Risk Factors. Acta Veterinaria Scandinavica, 43, 145-156. https://doi.org/10.1186/1751-0147-43-145

[28] Lo Fo Wong, D.M.A., Dahl, J., Stege, H., van der Wolf, P.J., Leontides, L., von Altrock, A. and Thorberg, B.M. (2004) Herd-Level Risk Factors for Subclinical Salmonella Infection in European Finishing-Pig Herds. Preventive Veterinary Medicine, 62, 253-266. https://doi.org/10.1016/j.prevetmed.2004.01.001

[29] Pritchard, G., Dennis, I. and Waddilove, J. (2005) Biosecurity: Reducing Disease Risks to Pig Breeding Herds. In Practice, 27, 230-237.

https://doi.org/10.1136/inpract.27.5.230

[30] Beltrán-Alcrudo, D., Arias, M., Gallardo, C., Kramer, S. and Penrith, M.L. (2017) African Swine Fever: Detection and Diagnosis. A Manual for Veterinarians. FAO Animal Production and Health Manual No. 19, Rome.

[31] Pensaert, M., Ottis, K., Vandeputte, J., Kaplan, M.M. and Bachmann, P.A. (1981) Evidence for the Natural Transmission of Influenza A Virus from Wild Ducts to Pig and Its Potential Importance for Man. Bulletin of the World Health Organization, 59, 75-78.

[32] Wall, P.G., Morgan, D., Lamden, K., Griffin, M., Threlfall, E.J., Ward, L.R. and Rowe, B. (1995) Transmission of Multi-Resistant Strains of Salmonella typhimurium from Cattle to Man. The Veterinary Record, 136, 591-592. https://doi.org/10.1136/vr.136.23.591

[33] Fritzemeier, J., Teuffert, J., Greiser-Wilke, I., Staubach, C., Schlüter, H. and Moennig, V. (2000) Epidemiology of Classical Pig Fever in Germany in the 1990s. Veterinary Microbiology, 77, 29-41. https://doi.org/10.1016/S0378-1135(00)00254-6

[34] Artois, M., Depner, K.R., Guberti, V., Hars, J., Rossi, S. and Rutili, D. (2002) Classical Pig Fever (Hog Cholera) in Wild Boar in Europe. Revue Scientifique et Technique de P OIE, 21, 287-303. https://doi.org/10.20506/rst.21.2.1332

[35] Rufino, M.C., Rowe, E.C., Delve, R.J. and Giller, K.E. (2006) Nitrogen Cycling Efficiencies through Resource-Poor African Crop-Livestock Systems. Agriculture, Ecosystems and Environment, 112, 261-282. https://doi.org/10.1016/j.agee.2005.08.028

[36] Ström, G., Albihn, A., Jinnerot, T., Boqvist, S., Andersson-Djurfeldt, A., Sokerya, S., Osbjer, K., San, S., Davun, H. and Magnusson, U. (2018) Manure Management and Public Health: Sanitary and Socio-Economic Aspects among Urban Livestock-Keepers in Cambodia. Science of the Total Environment, 621, 193-200. https://doi.org/10.1016/j.scitotenv.2017.11.254

[37] Thien Thu, C.T., Cuong, P.H., Hang, L.T., Chao, N.V., Anh, L.X., Trach, N.X. and Sommer, S.G. (2012) Manure Management Practices on Biogas and Non-Biogas Pig Farms in Developing Countries-Using Livestock Farms in Vietnam as an Example. 
Journal of Cleaner Production, 27, 64-71. https://doi.org/10.1016/j.jclepro.2012.01.006

[38] Teenstra, E.D., Vellinga, T.V., Aktasaeng, N., Amatayaku, W., Ndambi, A., Pelster, D., Germer, L., Jenet, A., Opio, C. and Andeweg, K. (2014) Global Assessment of Manure Management Policies and Practices (No. 844). UR Livestock Research, Wageningen. https://library.wur.nl/WebQuery/wurpubs/485932

[39] Gwavuya, S.G., Abele, S., Barfuss, I., Zeller, M. and Müller, J. (2012) Household Energy Economics in Rural Ethiopia: A Cost-Benefit Analysis of Biogas Energy. Renewable Energy, 48, 202-209. https://doi.org/10.1016/j.renene.2012.04.042

[40] James, K., Malcolm, A., Phouth, I., Kate, B., Axelle, S. and Socheat, S. (2013) Biosecurity Education for Traders to Reduce the Spread of Animal Diseases in Lao PDR and Cambodia: Cattle Health, Production and Trade in Cambodia. Proceedings from Three ACIAR Funded Projects Presented at an International Workshop, Phnom Penh, 7-8 June 2011, 141-146.

[41] Ribbens, S., Dewulf, J., Koenen, F., Maes, D. and de Kruif, A. (2007) Evidence of Indirect Transmission of Classical Pig Fever Virus through Contacts with People. The Veterinary Record, 160, 687-690. https://doi.org/10.1136/vr.160.20.687

[42] Amass, S.F., Halbur, P.G., Byrne, B.A., Schneider, J.L., Koons, C.W., Cornick, N. and Ragland, D. (2003) Mechanical Transmission of Enterotoxigenic Escherichia coli to Weaned Pigs by People, and Biosecurity Procedures That Prevented Such Transmission. Journal of Pig Health and Production, 11, 61-68.

[43] Ciarán, C., Laura, B., Shane, B., Seamas, C., Jim, F., Peadar, L., Brendan, L., Michael, M., Gerard, M., Michael, M., Amy, Q. and Pat, T. (2014) Biosecurity Procedures for Visitors to Pig Units in Ireland. Teagasc Pig Development Department. Second Edition.

[44] Board, N.P. (2019) Biosecurity of Pigs and Farm Security. Pork Information Gateway. http://porkgateway.org/resource/biosecurity-of-pigs-and-farm-security 